\title{
Assessing Boko Haram: A Conversation
}

\section{by Mark Amaliya and Michael Nwankpa}

\section{(cc) $\mathrm{BY}$}

This work is licensed under a Creative Commons Attribution 3.0 License

I $\mathrm{n}$ terms of the current terrorist organisations in Sub-Saharan Africa, Boko Haram is undoubtedly one of the most high profile and among the more long-established. Following a panel session on the group at the 2013 conference of the Society for Terrorism Research at the university of East London, two of the panellists discuss the conceptualisation of the group, the nature and scale of the threat posed by the group, and what responses might offer a viable route away from the violence that has affected particularly Northern Nigeria since the onset of the Boko Haram insurgency.

\section{Q1. Briefly, how would you describe Boko Haram as a group?}

\section{Mark Amaliya}

Typical of any group engaged in political violence, the radicalization, de-radicalization and re-radicalization of its group identity, ideology and modus operandi changes over time. In describing Boko Haram, two factors are worth noting. From 2002 to present, the sect's modus operandi and ideology have shifted to reflect emergent changes in the geo-political setting of the country. Boko Haram represents a modern reincarnation of the historical clash of civilizations between Traditional Islamic jurisprudence in the North of Nigeria and its amalgamation into the secular Nigerian nation state of 1914 interred in the colonial legacy of British rule.

The sect can thus be viewed as a conservative, fanatical Islamic sect, fundamentally opposed to secular statehood and western political ideology by engaging in a Jihad-inspired perpetuation of terror as its principal means to establish a Nigerian state rooted in Salafist proselytism. In terms of its structure and modus operandi, the organization could be categorised as amorphous (combining sophisticated combat techniques and technology with a variety of target victims), anonymous (due to the lack of an organised group of interlocutors with whom, policy agencies could engage), and internally fragmented without a centred leadership. From a strategic point of view, the sect depends heavily on media publicity and sporadic strikes in order to remain relevant as a counteractive force to the secular status quo. By so doing, its action align it to more established jihad networks such as Al-Qaida and its affiliates in Africa with a potential to evolve into a much greater threat across the continent.

However, Boko Haram's radicalization owes directly to the securitization and kinetic posture of Nigeria's state security services towards its membership in particular and the North in general, which has lent the group leverage to constitute itself as a de-facto pro-Northern militia, drawing sympathy from families of victims and empathy among the elite for what is generally considered a failure of the federal government to address inequality gaps in the north and improved public welfare.

\section{Michael Nwankpa}

Mark's observation about the evolutionary nature of extremist groups' ideologies and motives is consistent 


\section{Journal of Terrorism Research}

with views in the extant literature. However, the popular view about Boko Haram (BH) as "a conservative, fanatical Islamic sect, fundamentally opposed to secular statehood and western political ideology", a view supported by Mark, is just one slice of the cake, and may even be a misleading way of viewing $\mathrm{BH}$.

First, it is important to recognise that the project of imposing an Islamic social and political system in the secularised state of Nigeria - what is supposedly the political project of $\mathrm{BH}$ - is one that is not so far removed from some parts of the political mainstream. It is also an agenda that has been promoted by Northern leaders starting from General Murtala Muhammed (1975) and carried on by successive Northern heads of state such as Shehu Shagari (1979), General Buhari (1983), Ibrahim Babangida (1995), General Sani Abacha (1993), and, in a less clear way, by President Olusegun Obasanjo (1999) (Omoruyi, 2001). This itself raises a critical question: To what extent is $\mathrm{BH}$ operating alone or in alliance with those parts of the Northern leadership supportive of this broad political and social agenda?

This leads to a second point. If the motive of $\mathrm{BH}$ is or was ever to impose a Sharia political system on the secularised Nigerian state, that motive is now being relegated and supplanted by more pressing economic and political objectives. On the economic front, there has been the turn by some BH elements to what we might talk about as rogue or criminal $\mathrm{BH}$ activities akin to those used by the Niger Delta militants - in the kidnapping of foreigners and ransom-seeking from foreign governments (such as the alleged $\$ 3 \mathrm{~m}$ ransom paid for the release of the kidnapped French family of 7 in April, 2013). It is this rogue BH element that is likely to have engaged the Nigerian government in dialogue and talk about amnesty. Underlying these criminal activities is the political goal of creating a vacuum or political space where northern leadership can emerge. Following the direct and indirect indictment of several members of the Northern leadership, such as Senator Ali Ndume (Borno), Senator Khalifa Zanna (Borno), former governor of Borno (Ali Modu Sheriff), and late Saidu Pindar (Nigeria’s former ambassador to Sao Tome \& Principe) as financial supporters of BH (The Nation, 2012) it is not far-fetched to argue that BH's main motive is to tilt the balance of power or guarantee the control and domination of power by the north.

\section{Mark Amaliya}

Michael makes a salient point in noting that an Islam-centric characterization of $\mathrm{BH}$ risks undermining other intrinsic and less manifest motives of the sect. While noteworthy, it is however equally critical to note that an interpretation of $\mathrm{BH}$ that centres on political motives may also lose sight of the fluid interaction between the economic, political and ethno-religious aspects of this conflict. I would propose that any attempt to view the specific dominance of any one of these aspects (the political or economic), at any given evolutionary stage of the sect as opposed to its self-proclaimed objective of establishing an Islamic State and countering western political hegemony may lead to a reductionist analysis of the group's ideology. Furthermore, one ought not to conflate the sect's operational means with its desired end. The argument that BH's anti-secular fascism is being supplanted by economic crime and political sponsorship confuses the sect's modus operandi with its primary end of disenabling the status quo.

In his submissions, Michael cites in the first instance, an upsurge in kidnappings and ransom claims by the sect as an ideological shift from anti-secularism without acknowledging the larger domain of subaltern economic crime in the country where kidnappings and celebrity abductions thrive independent of Islamic political extremism. I would also question the argument of northern political sponsorship to the group as a strategy to create a power vacuum to be filed by Northern political elite. There exist notable cases that contradict such a linear progression. The most iconic being the fact that the greatest crackdown on $\mathrm{BH}$ occurred in 2009 during the tenure of President Umaru Musa Yar'Adua, who hailed from northern Nigeria. 
At this critical moment one could label the incident as a Northern insurgency against a Northern incumbent. The sect has also targeted Northern political elites including the Sarduana of Sokoto and has been ruthless in bombing northern mosques, schools and security installations believed to be unsympathetic to their course. Thus any semblance of northern political alliance in the Boko haram struggle should be seen more as a marriage of convenience and less an ideological shift.

\section{Michael Nwankpa}

Mark's argument is compatible with my views that the activities of $\mathrm{BH}$ are motivated by a combination of several factors including politics, economics and ethno-religion, and that any attempt at elevating one factor above the others may undermine, rather than help our understanding of the group. Yet he still appears to hold a preference for an explanation based on an Islamist motivation, while I would emphasise a strong political undertone. Further evidence for this position would seem to come from the fact observed by the late General Owoeye Azazi, National Security Adviser to President Jonathan, that "the issue of violence did not increase in Nigeria until there was a declaration by the current President that he was going to contest" (Channels, 2012). In other words, the increase in violence coincided with and might even be read as a response to wider political developments.

\section{Q2: What, in your assessment, is the scale of threat posed by Boko Haram to the Nigerian state?}

\section{Michael Nwankpa}

In order to develop an analysis of the threat posed by BH to the Nigerian state, it would be wise to break this down into a discussion of the different types of threat that the group might be seen to pose: economic, sociopolitical and security/counter-terrorism.

From an economic perspective, $\mathrm{BH}$ does not pose a serious direct threat to the Nigerian state, particularly when compared to the Niger Delta insurgency (which impacts directly on the country's economic mainstay, oil). It does however pose an indirect economic threat, as the state of insecurity it creates discourages potential local and foreign investors from investing in the northern as well as other parts of Nigeria.

The most substantial threat posed by BH is a socio-political threat. First, BH's agenda (if it is to Islamise Nigeria) is incompatible with the secular nature of the Nigerian state. Secondly, its disproportionate attacks on peoples and properties of other religion (faith) and ethnicity can fuel ethno-religious sentiments and conflicts. Such ethnic and religious sentiments and conflicts can turn into sectarian war (evident in the reprisal and/or threat of reprisal attack from the Christian Association of Nigeria [CAN]) or a large scale civil war similar to the Nigeria-Biafra Civil War of 1967-1970.

From a counter-terrorism perspective, $\mathrm{BH}$ can also be seen to pose a substantial threat, albeit one that would appear to be relatively concentrated geographically: with the exception of the suicide bombing attacks on the police headquarters, United Nations building, and a newspaper [ThisDay] property in Abuja-the capital city, BH's coordinated attacks have been largely confined to the northern region, or even some northern states such as Borno, Yobe and Adamawa. Yet in spite of the opportunities that BH's limited operational space would seem to offer for the Nigerian government to concentrate its full resources geographically in order to curb the situation, the Joint Task Force (JTF) has been unable to disband $\mathrm{BH}$, and $\mathrm{BH}$ has been able to maintain vigorous and sustained attacks on its victims 


\section{Journal of Terrorism Research}

\section{Mark Amaliya}

Boko Haram's ability to challenge the State's monopoly over the use of force constitutes its greatest threat. This threat poses both a physical challenge to the survival of the Nigerian state, and a psychological challenge that threatens to undermine civic engagement.

Physically, Boko Haram represents a challenge to the underlying political principles of political autonomy and territorial inviolability. The present security standoff, along with a history of economic, political and institutional ineptitude has led some observers to categorise the country in the family of fragile states, or even to call it a 'dysfunctional state' (Lewis 2006). Any advancement in Boko Haram's lethal attacks and operational scope would arguably risk the country sliding into the pariah category of 'failed states', in particular as such a development might establish a condition for an infiltration of violent allies such as $\mathrm{Al}$ Qaida, thus leading to a similar scenario as that which developed in Somalia.

Psychologically, the persistence and lethality of the sect's attacks has created an atmosphere of insecurity and uncertainty in civic life and social congregation, which has done much to disrupt the activities that comprise Nigeria's public sphere. Failure to contain and control the attacks by Boko Haram has left a community subjected to fear, hindering political organization and stifling private sector activity.

The physical and psychological dimensions of the threat posed by $\mathrm{BH}$ have combined to generate a toxic context of suspicion and distrust of the state and its authority. This has manifested in several ways. We have seen the emergence of a number of self-help community initiatives including the formation of vigilante militia groups in Maiduguri, there have been repeated charges of vested partisan interest and sponsorship of the sect's activities by political parties, as well as a more general inflaming of ethnic tensions regarding issues of Islamic fanaticism in the north and concentrations of oil wealth in the south. Furthermore, the conduct of the State Security Services (SSS) has done little to inspire public confidence in the authority of the state. Following reports of corruption, human rights abuses and extra judicial killings (see Human Rights Watch Report 2013), operations of the JTF have increasingly tarnished its professional image and raised questions regarding the disproportionality of force being expended.

\section{Michael Nwankpa}

Yet the fact is that the scale of casualties and property losses associated with the current conflict with Boko Haram is not as great as those associated with the wider wave of ethno-religious violence that has taken place in the North of Nigeria in recent years. In Jos alone, the deadly cycle of violence has claimed, besides damaged properties, more than a conservative figure of 5000 lives in a decade (2000-2010).

This raises the crucial question of why Boko Haram has received so much attention in comparison with the wider violence. There would appear to be a few reasons for this. One of these is arguably the fear that the group may be particularly susceptible to infiltration by, and provide a vehicle for, more dangerous global terrorist organisations (that is if this has not already taken place) such as Al Qaeda and Al Shabab. Related to this is the group's increased targeting of foreign nationals and the damage that Boko Haram is able to do to Nigeria's relations with other countries whose business and personal interests are affected negatively by the conflict. In addition, the failure of the Nigerian state to curb the activities of $\mathrm{BH}$ in spite of an apparently significant investment of resources means that $\mathrm{BH}$ has been capable of inflicting particularly significant symbolic damage on the Nigerian state apparatus both in domestic and international arenas. 


\section{Journal of Terrorism Research}

\section{Q3: What are the potential avenues towards a solution to the violence and hostilities associated with Boko Haram? What are the key issues that need to be addressed?}

\section{Michael Nwankpa}

In spite of the wide range of counter-terrorism measures (including direct force, declarations of a state of emergency, curfews and counter-narratives), the end of the conflict seems far away (even though the Nigerian military's public relations department would have us think otherwise).

What seems clear is that military force, and especially military force alone, is not the solution to the violence and tension associated with $\mathrm{BH}$. There is no doubt that the Nigerian military is overwhelmingly more powerful than $\mathrm{BH}$, but what is doubtful is how well suited it is to overcome a force like the $\mathrm{BH}$ insurgents. The loose and hilly spatial character of the northern states and the porous borders between the northern states and neighbouring countries such as Chad and Cameroon make it possible for the insurgents to retreat and engage the military using guerrilla tactics. The federal composition of Nigeria's force and the history of deploying soldiers from separate ethnic groups to quell crises in other ethnic regions make it difficult for the force to overcome $\mathrm{BH}$, as they most times do not understand the terrain better than the local insurgents.

Given the limitations on the use of large-scale military force, there is a clear need for the adoption of intelligence-led responses - responses that will help the military achieve precise and accurate targeting, avoiding the kind of collateral damage that can play into the hands of the insurgents. Yet to date, Nigeria lacks a suitable counter-terrorism intelligence structure. The three Intelligence structures - Defence Intelligence Agency (DIA) National Intelligence Agency (NIA) and State Security Service (SSS) - created in 1986 by Babangida to cater for military, foreign and domestic intelligence respectively do not have the capacity to engage the terror posed by $\mathrm{BH}$. The mandate of the SSS leans more on the protection of public officials. One way forward could be the development of a dedicated counter-terrorism centre (similar to the Joint Terrorism Analysis Centre [JTAC] in the United Kingdom). This should not be confused with the Nigerian military's endorsement of a civilian Joint Task Force (a civilian arm of the military JTF, comprising of little more than local youth vigilante groups).

More broadly, any more targeted response to $\mathrm{BH}$ violence needs to go hand in hand with a serious and credible effort to improve the living standards of the people of the region. This could take the form of Government investment in infrastructure, education, in creating job opportunities for the largely impoverished populace of the Northern states, and ought also include a programme of improving the provision of social welfare, respect of human rights and fight against corruption among public officials. This will help mitigate the attraction of $\mathrm{BH}$ to young people, who make up a large number of the group's recruit.

\section{Mark Amaliya}

The main avenue towards a lasting solution is for the state to prioritize and broaden non-violent approaches. Among some of the nonviolent counter terror-initiatives already implemented by the government, the following are noteworthy: the passing of the Terrorism Prevention Amendment (TPA) in February 2013, a directive for judicial clarity on competency issues between State and Federal courts regarding their jurisdictional powers over crimes committed by members of the sect and the expeditious prosecution 


\section{Journal of Terrorism Research}

of suspects (OTP-ICC report 2013). Also, the president set up the Committee on Dialogue and Peaceful Resolution of Security Challenges in the North (OTP-ICC report 2013: 50).

While laudable, most of these interventions have either stalled in the process of implementation or failed to command authority on the ground, not helped by allegations of extra judicial killings and the unlawful release of arrested suspects. Furthermore, only marginal gains have been achieved in the area of negotiations as the work of the committee on dialogue failed to engage the leadership of Boko Haram in dialogue until the submission of its report to the president on November 12, 2013. The committee also suffered the early withdrawal of a key negotiator, Dr. Ahmad Ibrahim Datti, President General of the Supreme Council for Sharia in Nigeria (SCSN), who cited a lack of trust in government's commitment to implement committee findings following his previous experience serving on a similar panel (Binnyat 2013).

The search for a reliable exit out of conflict requires coherency in terms of policy objectives and their respective strategies of implementation. The need to maintain consistency begins with the language of political leaders. To demonstrate such consistency, epithets like 'faceless cowards' and 'ghosts' which have repeatedly been used by President Goodluck Jonathan to describe the sect should be avoided, since they undermine efforts at building trust between the government and the leadership of the sect.

Secondly, a unified and channel of consultative engagement with Boko Haram is necessary. Past forms of engagement with Boko Haram, have been characterised by a multiplicity of bodies and individuals striving to negotiate with the sect, resulting in disparate proposals without a clear strategy. For instance, Coalitions such as the Forum of Northern Governors, whose attempts in the past to localize dialogue and explore ceasefire incentives for the group risked impeding the efforts being formulated at the federal level in terms of a duplication of functional roles and authority.

Other important target groups include CSOs, researchers and multilateral partners. CSOs mainly in the areas of governance and advocacy should work to address problems of illiteracy, youth unemployment and good governance. In addition, the government should allocate more funds towards research and development in the field of domestic radicalism and security in the north. Some essential focal areas include research on the evolution of traditional and post-independence Muslim cultures, exploring avenues of cultural integration and setting up a national centre for the study of radicalism.

Finally, domestic counter-terrorism measures should be complemented with an effective regional and global collaborative strategy. Noting the challenges associated with border security, money laundering and trans-border crime, the ECOWAS sub-region must prioritize strengthening trans-border security, intelligence gathering and sharing across neighbouring countries. However, in taking steps towards such coordination, it is important to be wary of the tendency for the undue securitization of domestic threats from the transnational level. For instance, the recent designation of Boko Haram and its spinoff group Ansaru as Foreign Terrorist Organizations by the USA on November $13^{\text {th }} 2013$ and the release of an ICC report indicting boko haram for committing crimes against humanity and classifying the armed violence between Boko Haram and Nigerian security forces as an 'armed conflict of non-international character' (OTP ICC report 2013) present an opportunity for a heavy handed global response to the sect's activities. The real challenge for the Nigerian state is how to synergise cooperation between the various actors, maintaining the state as the principal protagonist on the ground and exhausting all avenues to peaceful resolutions before resorting to drastic humanitarian interventions. 


\section{Journal of Terrorism Research}

\section{About the authors:}

Mark Amaliya Anyorikeya holds a Master of Public Policy degree from the Willy Brandt School of Public Policy at the University of Erfurt, Germany. His current area of research includes; Terrorism in Africa and the rise of Violent Non State Actors within the ECOWAS sub-region.

Michael Nwankpa is a PhD candidate in the University of Roehampton, London. He is an expert on counterterrorism and counter-insurgency in Africa. He is presently working on the application of development and human rights approaches to the Boko Haram and Niger Delta Conflicts in Nigeria.

\section{References}

Binnyat L. (2012, April 17); Nigeria: Boko Haram - Ahmed Datti Withdraws From Committee, Vanguard. www.allafrica.com/stories/201304190264.html

Channels (2012, April 17), Azazi blames Boko Haram attacks on PDP, http://www.channelstv.com/ home/2012/04/27/azazi-blames-boko-haram-attacks-on-pdp/

Accessed on (9.08.2013)

Lewis M.P (2006): The Dysfunctional State of Nigeria: cited in Ayres L.R., Birdshall N and Vaishnav M. (EDs): Short of the Goal, US Policy and Poorly Performing States: Centre for Global Development: Washington D.C.

Human Rights Watch Report (2013, October 17), “Nigeria UPR Submission March (2013)”: http://www.hrw. org/news/2013/10/17/nigeria-upr-submission-march-2013 (Accessed on 17.10.2013).

Office of the Prosecutor -International Criminal Court (2013, August 5), "Situation in Nigeria Article 5 Report”. http://www.icccpi.int/iccdocs/PIDS/docs/SAS\%2520\%2520NGA\%2520\%2520Public\%252 version\% 252Article\%25205\%2520Report\%2520-\%252005\%2520August\%25202013.PDF (Accessed on 25.11.2013).

Office of the Prosecutor, International Criminal Court (2013, November), “Report on Preliminary Examination Activities”. http://www.icccpi.int/en menus/icc/press\%20and\%20media/press\%20releases/ Documents/OTP\%20Preliminary\%20Examinations/OTP\%20\%20Report\%20\%20Preliminary\%20 Examination\%20Activities\%202013.PDF (Accessed on 25.11.2013)

Omoruyi, O. (2001). An Appeal to President Olusegun Obasanjo: Nigeria: Neither an Islamic nor a Christian Country. http://www.biafraland.com/Islamization\%20of\%20Nigeria.htm

Taylor M. (2013): Expert Interview; Jacob Zenn on Terrorism and Insurgency in Northern Nigeria: African Arguments: http://africanarguments.org/2013/10/24/expert-interview-jacob-zenn-on-terrorism-andinsurgency-in-northern-nigeria/. (Accessed on 24.10.2013)

The Nation (2012, October); published on AfricanSpotlight.com, 'PDP, Senator behind Boko Haram' - ExBorno State Governor'. http://www.africanspotlight.com/2012/10/25/pdp-senator-behind-boko-haram-exborno-state-governor/ (Accessed on 30.10.2013) 